\title{
PENGARUH KARAKTERISTIK PEROKOK AKTIF PADA PENDERITA HIPERTENSI DI UPT PUSKESMAS DASUK
}

Mujib Hannan, Program Studi IImu Keperawatan UNIJA Sumenep,

e-mail; Mujib@wiraraja.ac.id

Zakiyah Yasin, Program Studi Profesi Ners UNIJA Sumenep,

e-mail; zakiyahyasin@yahoo.co.id

Syaifurrahman Hidayat, Program Studi IImu Keperawatan UNIJA Sumenep,

e-mail; dayat.fik@wiraraja.ac.id

\section{ABSTRACT}

Smoking is one of the habits that can affect blood pressure, from the data UPT Puskesmas Dasuk number of people with hypertension in 2011 patients reported as much as $7.85 \%$ and 8.05\% in 2012 as many people with it have increased. This study was conducted to determine Preview Smoker Active In Patients with Hypertension In UPT Puskesmas Dasuk Sumenep City District in 2016..

Descriptive research design. Population of hypertensive patients in UPT Puskesmas Dasuk in 2016 as many as 146 people. Sample were 29 respondents to the inclusion criteria were active smokers with hypertension and at UPT clinic Dasuk. Variabelnya is characteristic of active smokers. Collecting data using questionnaires, the data were, conclusions and suggestions.

Nearly half of the 29 respondents 14 (48.3\%) aged 60-74 years, the majority of 17 (58.6\%) had elementary / Not The End SD, 9 Nearly half (31.0\%) work Entrepreneurs, Nearly Half 13 (44.9\%) respondents blood pressure stage 3, Most of the 20 (69.0\%) smoked more than> 10 in a day, Most of the 17 (58.6\%) smoked> 20 years., Most of the 19 (65.5\%) smoked type of filter., Most of the $16(55.1 \%)$ smoked after a meal.

Nurse attempts to overcome the problem of active smokers in patients with hypertension in UPT Puskesmas Dasuk to provide information about the dangers of cigarette smoking is expected to know about the dangers of smoking and nothing else.

Keywords: Characteristics of Active Smokers, People with Hypertensio

\section{PENDAHULUAN}

Merokok merupakan salah satu kebiasaan hidup yang dapat mempengaruhi tekanan darah (Wardoyo, 1996: 28). Meski semua orang tau akan bahaya yang ditimbulkan akibat merokok, kebiasaan merokok tidak pernah surut dan tampaknya merupakan perilaku yang masih dapat ditolerir oleh masyarakat. Hal ini dapat dirasakan dalam kehidupan sehari - hari di lingkungan rumah, angkutan umum, maupun di jalan-jalan. Hampir setiap saat dapat dijumpai orang sedang merokok. Bahkan bila orang merokok disebelah ibu yang sedang menggendong bayi sekalipun, orang tersebut tetap tenang menghembuskan asap rokoknya dan biasanya orang-orang yang ada di sekelilingnya sering kali tidak peduli.

Dari data WHO tahun 2009 tersebut, Indonesia dinobatkan sebagai negara dengan konsumsi rokok terbesar nomor 3 setelah China dan India dan diatas Rusia dan Amerika Serikat. Padahal dari jumlah penduduk , Indonesia berada di posisi ke-4 yakni setelah China, India dan Amerika Serikat. Ini jauh meningkat dibandingkan tahun 2002. Menurut
Departemen Kesehatan melalui pusat promosi kesehatan menyatakan Indonesia merupakan salah satu negara berkembang yang memiliki tingkat konsumsi rokok dan produksi rokok tertinggi. Berdasarkan data dari WHO tahun 2002 Indonesia menduduki urutan ke 5 terbanyak dalam konsumsi rokok di dunia dan setiap tahunnya mengkonsumsi 2,5 miliar batang rokok.

Angka kematian bagi perokok $70 \%$ lebih tinggi dibandingkan dengan non perokok terutama bagi pria berusia 45 - 54 tahun. Penelitian di Inggris menunjukkan jumlah perokok 25 batang setiap hari (berusia 35 tahun), $40 \%$ diantaranya akan meninggal sebelum berusia 65 tahun. Dari sisi kesehatan, bahaya merokok sudah tidak dibantahkan, bukan hanya menurut $\mathrm{WHO}$, tetapi lebih dari 70 ribu artikel ilmiah membuktikan bahwa dalam kepulan asap rokok terkandung 4000 racun kimia berbahaya dan 43 diantaranya itu adalah tar, karbonmonoksida (CO) dan nikotin. Dan berbagai penyakit kanker pun mengintai serta dapat menimbulkan hipertensi. (Abadi, 2005). 
Dari hasil Sussenas (Survei Sosial Ekonomi Nasional) 2001 menyatakan bahwa $54 \%$ penduduk laki-laki merupakan perokok dan hanya $1,2 \%$ perempuan yang merokok. Menurut Edward D Frohlich, seorang pria dewasa akan mempunyai peluang lebih besar yakni satu diantara lima untuk mengidap hipertensi (Lanny Sustrani, 2004:25). Berdasarkan data dari Dinas Kesehatan Kabupaten Sumenep, Hipertensi merupakan penyakit ketiga terbesar setelah ISPA dan gangguan lain pada jaringan otot di tahun 2011 dengan jumlah 14140 orang (6,28\%). Pada tahun 2012 terdapat 14122 pasien hipertensi dari bulan Januari sampai bulan September (Dinkes Sumenep, 2012).

Dari hasil rangkuman data pemeriksaan pada tahun 2011 jumlah pasien Hipertensi di puskesmas Dasuk mencapai 1056 (7,85\%) penderita sedangkan pada tahun 2012 pasien hipertensi mencapai 1137 (8,05\%) penderita,yang merupakan penyakit kedua tertinggi setelah ISPA. Sehingga dapat disimpulkan bahwa hipertensi merupakan masalah yang masih harus diperhatikan. Data tersebut menunjukkan bahwa kasus kejadian hipertensi diwilayah kerja Puskesmas Dasuk mengalami peningkatan,baik untuk kasus lama maupun kasus baru (Dinkes Sumenep, 2012).

Maka dari itu penyakit hipertensi pada saat ini merupakan problem kesehatan masyarakat yang memerlukan penanganan dengan serius, mengingat hipertensi tidak dapat disembuhkan tetapi dapat dikendalikan. Salah satu cara untuk mengatasi hipertensi adalah dengan mencegah kebiasaan masyarakat merokok. Karena rokok dapat mendorong timbulnya tekanan darah, Kanker, serangan Jantung, Impotensi dan gangguan Kehamilan dan Janin

\section{BAHAN DAN METODE}

Dalam hal ini metode penelitian yang digunakan adalah penelitian Deskriftif karena bertujuan untuk mengetahui gambaran atau deskripsi tentang suatu keadaan secara objektif dan untuk memecahkan suatu masalah atau menjawab permasalahan yang sedang dihadapi pada situasi sekarang. Menurut waktunya desain penelitian yang di gunakan adalah cross sectional, karena objek penelitian sesaat saja. Sampel pada penelitian ini adalah semua pengunjung atau pasien yang datang ke Puskesmas Dasuk Kecamatan Dasuk Kabupaten Sumenep Pada Tahun 2016 yaitu sebanyak 146 orang dan populasi penderita penyakit hipertensi yang perokok aktif .Variable Karakteristik Perokok Aktif
HASIL

Karakteristik responden berdasarkan umur

Berdasarkan hasil kuesioner yang telah dibagikan, diperoleh hasil mengenai distribusi frekuensi responden menurut umur, yang terdapat pada tabel di bawah ini:

\begin{tabular}{clcc}
\hline No & \multicolumn{1}{c}{ Umur } & $\sum$ & $\%$ \\
\hline 1 & $40-59$ Tahun (Usia & 13 & $44,8 \%$ \\
2 & $\begin{array}{l}\text { Pertengahan) } \\
60-74 \text { Tahun (Lansia) }\end{array}$ & 14 & $48,3 \%$ \\
3 & $\begin{array}{l}75-90 \text { Tahun (Lanjut } \\
\text { Usia) }\end{array}$ & 2 & $6,9 \%$ \\
4 & $\begin{array}{l}>90 \text { Tahun (Usia Sangat } \\
\text { Tua) Total }\end{array}$ & 0 & $0 \%$ \\
& 29 & $100,0 \%$ \\
\hline
\end{tabular}

Dari hasil distribusi frekuensi didapatkan bahwa hampir setengah dari responden berumur $60-74$ tahun yaitu sebanyak 14 responden atau $48,3 \%$ dari total sampel.

\section{Karakteristik responden berdasarkan Pendidikan}

Berdasarkan hasil kuesioner yang telah dibagikan, diperoleh hasil mengenai distribusi frekuensi responden menurut pendidikan, yang terdapat pada tabel di bawah ini:

\begin{tabular}{clcc}
\hline No & \multicolumn{1}{c}{ Pendidikan } & $\sum$ & $\%$ \\
\hline 1 & SD/Tidak tamat SD & 17 & $58,6 \%$ \\
2 & SMP & 4 & $13,8 \%$ \\
3 & SMA & 5 & $17,2 \%$ \\
4 & Akademi/PT & 3 & $10,4 \%$ \\
& Total & 29 & $100,0 \%$ \\
\hline
\end{tabular}

Dari hasil distribusi frekuensi didapatkan bahwa sebagian besar responden berpendidikan SD/Tidak tamat SD yaitu sebanyak 17 responden atau $58,6 \%$ dari total sampel.

\section{Karakteristik responden berdasarkan Pekerjaan}

Berdasarkan hasil kuesioner yang telah dibagikan, diperoleh hasil mengenai distribusi frekuensi responden menurut pekerjaan, yang terdapat pada tabel di bawah ini:

\begin{tabular}{|c|c|c|c|}
\hline No & Pekerjaan & $\sum$ & $\%$ \\
\hline 1 & PNS & 4 & $13,8 \%$ \\
\hline 2 & Wiraswasta & 9 & $31,0 \%$ \\
\hline 3 & Petani & 8 & $27,6 \%$ \\
\hline 4 & Tidak Kerja & 8 & $27,6 \%$ \\
\hline & Total & 29 & $100,0 \%$ \\
\hline
\end{tabular}

Dari hasil distribusi frekuensi didapatkan bahwa hampir setengah dari responden kerjanya Wiraswasta yaitu sebanyak 9 responden atau $31,0 \%$ dari total sampel.

\section{Karakteristik responden berdasarkan Tekanan Darah}

Berdasarkan hasil kuesioner yang telah dibagikan, diperoleh hasil mengenai distribusi 
frekuensi responden menurut tekanan darah, yang terdapat pada tabel di bawah ini:

\begin{tabular}{cccc}
\hline No & Tekanan Darah & $\sum$ & $\%$ \\
\hline 1 & Stadium I 140-159 & 6 & $20,6 \%$ \\
2 & Stadium 2 > 160 & 10 & $34,5 \%$ \\
3 & Stadium 3 > 180 & 13 & $44,9 \%$ \\
& Total & 29 & $100,0 \%$ \\
\hline
\end{tabular}

Dari hasil distribusi frekuensi didapatkan bahwa sebagian besar dari responden tekanan darahnya Stadium $3>180$ yaitu sebanyak 13 atau $44,9 \%$ dari total sampel.

\section{Karakteristik responden berdasarkan Banyak Rokok yang Dihisap}

Berdasarkan hasil kuesioner yang telah dibagikan, diperoleh hasil mengenai distribusi frekuensi responden menurut jumlah rokok yang dihisap, yang terdapat pada tabel di bawah ini:

\begin{tabular}{cccc}
\hline No & $\begin{array}{c}\text { Banyak Rokok yang } \\
\text { Dihisap }\end{array}$ & \multicolumn{1}{c}{$\Sigma$} & \multicolumn{1}{c}{$\%$} \\
\hline 1 & 1- 4 Batang (Ringan) & 1 & $3,4 \%$ \\
2 & 5-10 Batang (Sedang) & 8 & $27,6 \%$ \\
3 & $>10$ Batang (Berat) & 20 & $69,0 \%$ \\
& Total & 29 & $100,0 \%$ \\
\hline
\end{tabular}

Dari hasil distribusi frekuensi didapatkan bahwa sebagian besar dari responden perokok $>10$ batang yaitu sebanyak 20 responden atau $68,9 \%$ dari total sampel.

\section{Karakteristik responden berdasarkan Lama Merokok}

Berdasarkan hasil kuesioner yang telah dibagikan, diperoleh hasil mengenai distribusi frekuensi responden menurut lama merokok, yang terdapat pada tabel di bawah ini:

Tabulasi Silang Umur dengan tekanan darah

\begin{tabular}{lccccccccc}
\hline & \multicolumn{9}{c}{ Tekanan Darah } \\
\hline Umur & \multicolumn{1}{c}{ stadium 1: } & $140-159$ & \multicolumn{2}{c}{ stadium : $2>160$} & \multicolumn{1}{c}{ Stadium 3: $>180$} & \multicolumn{2}{c}{ Jumlah } \\
\cline { 2 - 9 } & $\mathrm{F}$ & $\%$ & $\mathrm{f}$ & $\%$ & $\mathrm{~F}$ & $\%$ & $\mathrm{f}$ & $\%$ \\
\hline $40-59$ & 4 & 30,8 & 4 & 30,8 & 5 & 38,4 & 13 & 100 \\
$60-74$ & 2 & 14,2 & 5 & 35,8 & 7 & 50,0 & 14 & 100 \\
$75-90$ & 0 & 0 & 1 & 50,0 & 1 & 50,0 & 2 & 100
\end{tabular}

Dari hasil Tabulasi Silang didapatkan bahwa dari 29 sampel responden yang berumur 40 - 59 tahun yang tekanan darahnya stadium 1 ada $30,8 \%$ responden , stadium 2 ada $30,8 \%$ responden, stadium 3 ada 38,4\% responden, responden yang berumur $60-74$ tahun yang tekanan darahnya stadium 1 ada $14,2 \%$

\begin{tabular}{cccc}
\hline No & Lama Merokok & $\sum$ & $\%$ \\
\hline 1 & $<10$ Thun & 0 & $0,0 \%$ \\
2 & $>10$ Tahun & 12 & $41,4 \%$ \\
3 & $>20$ Tahun & 17 & $58,6 \%$ \\
& Total & 29 & $100,0 \%$ \\
\hline
\end{tabular}

Dari hasil distribusi frekuensi didapatkan bahwa sebagian besar dari responden yang responden atau $58,6 \%$ dari total sampel.

\section{Karakteristik responden berdasarkan Jenis Rokok yang Dihisap}

Berdasarkan hasil kuesioner yang telah dibagikan, diperoleh hasil mengenai distribusi frekuensi responden menurut Jenis Rokok yang Dihisap, yang terdapat pada tabel di bawah ini:

\begin{tabular}{|c|c|c|c|}
\hline No & Jenis Rokok & $\sum$ & $\%$ \\
\hline 1 & Filter & 19 & $65,5 \%$ \\
\hline 2 & Non Filter & 10 & $34,5 \%$ \\
\hline
\end{tabular}

Dari hasil distribusi frekuensi didapatkan bahwa sebagian besar dari responden merokok jenis filter yaitu sebanyak 19 responden atau $65,5 \%$ dari total sampel.

\section{Karakteristik responden berdasarkan Waktu Merokok}

Berdasarkan hasil kuesioner yang telah dibagikan, diperoleh hasil mengenai distribusi frekuensi responden menurut waktu merokok, yang terdapat pada tabel di bawah ini:

\begin{tabular}{clcc} 
No & Waktu Merokok & $\sum$ & $\%$ \\
\hline 1 & Habis Makan & 16 & $55,1 \%$ \\
2 & Minum Kopi & 9 & $31,1 \%$ \\
3 & Santai & 4 & $13,8 \%$ \\
& $\quad$ Total & 29 & $100,0 \%$ \\
\hline
\end{tabular}

Dari hasil distribusi frekuensi didapatkan bahwa sebagian responden waktu merokok habis makan yaitu sebanyak 16 responden atau $55,1 \%$ dari total sampel. merokok >20 tahun yaitu sebanyak 17 responden, stadium 2 ada $35,8 \%$ responden, stadium 3 ada $50,0 \%$ responden dan responden yang berumur 75 - 90 tahun yang tekanan darahnya stadium 2 ada $50,0 \%$ responden, stadium 3 ada $50,0 \%$ responden, dari total sampel 
Tabulasi Silang Pendidikan dengan tekanan darah

\begin{tabular}{|c|c|c|c|c|c|c|c|c|}
\hline \multicolumn{9}{|c|}{ Tekanan Darah } \\
\hline \multirow[t]{2}{*}{ Pendidikan } & \multicolumn{2}{|c|}{ stadium 1: $140-159$} & \multicolumn{2}{|c|}{ stadium : $2>160$} & \multicolumn{2}{|c|}{ Stadium 3: >180 } & \multicolumn{2}{|c|}{ Jumlah } \\
\hline & $\mathrm{F}$ & $\%$ & $f$ & $\%$ & $f$ & $\%$ & $f$ & $\%$ \\
\hline $\begin{array}{l}\text { SD/Tidak Tamat } \\
\text { SD }\end{array}$ & 4 & 23,6 & 5 & 29,4 & 8 & 47,0 & 17 & 100 \\
\hline SMP & - & - & 3 & 75,0 & 1 & 25,0 & 4 & 100 \\
\hline SMA & 2 & 40,0 & 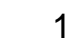 & 20,0 & 5 & 40,0 & 5 & 100 \\
\hline Akademi/PT & - & - & 1 & 33,3 & 2 & 66,7 & 3 & 100 \\
\hline \multicolumn{4}{|c|}{$\begin{array}{l}\text { Dari hasil tabulasi silang didapatkan bahwa } \\
\text { dari } 29 \text { sampel responden yang berpendidikan } \\
\text { SD/Tidak Tamat SD yang tekanan darahnya } \\
\text { stadium } 1 \text { ada } 23,6 \% \text { responden, stadium } 2 \\
\text { ada } 29,4 \% \text { responden, stadium } 3 \text { ada } 47,0 \% \\
\text { responden, responden yang berpendidikan } \\
\text { SMP yang tekanan darahnya stadium } 2 \text { ada } \\
75,0 \% \text { responden, stadium } 3 \text { ada } 25,0 \%\end{array}$} & \multicolumn{5}{|c|}{$\begin{array}{l}\text { responden, responden yang berpendidikal } \\
\text { SMA yang tekanan darahnya stadium } 1 \text { ad } \\
40,0 \% \text { responden, stadium } 2 \text { ada } 20,0 \% \\
\text { responden, stadium } 3 \text { ada } 40,0 \% \text { responden } \\
\text { responden yang berpendidikan Akademi } / P \\
\text { yang tekanan darahnya stadium } 2 \text { ada } 33,3 \% \\
\text { responden, stadium } 3 \text { ada } 66,7 \% \text { responde } \\
\text { dari total sampel. }\end{array}$} \\
\hline
\end{tabular}

Tabulasi Silang Pekerjaan dengan tekanan darah

\begin{tabular}{lcccccccc}
\hline \multirow{2}{*}{ Pekerjaan } & \multicolumn{9}{c}{ Tekanan Darah } \\
\cline { 2 - 9 } & $\mathrm{s}$ & $\%$ & $\mathrm{f}$ & $\%$ & $\mathrm{~F}$ & $\%$ & $\mathrm{~F}$ & $\%$ \\
\hline PNS & 1 & 25,0 & 1 & 25,0 & 2 & 50,0 & 4 & 100 \\
Wiraswasta & 3 & 33,3 & 3 & 33,4 & 3 & 33,3 & 9 & 100 \\
Petani & 1 & 12,5 & 4 & 50,0 & 3 & 37,5 & 8 & 100 \\
Tidak Kerja & 1 & 12,5 & 2 & 25,0 & 5 & 62,5 & 8 & 100 \\
\hline
\end{tabular}

Dari hasil tabulasi silang didapatkan bahwa dari 29 sampel responden yang bekerja PNS yang tekanan darahnya stadium 1 ada $25,0 \%$ responden, stadium 2 ada 25,0\% responden, stadium 3 ada $50,0 \%$ responden, responden yang bekerja Wiraswasta yang tekanan darahnya stadium 1 ada $33,3 \%$ responden, stadium 2 ada 33,4\% responden, stadium 3 ada

$33,3 \%$ responden, responden yang berkerja Petani yang tekanan darahnya stadium 1 ada $12,5 \%$ responden, stadium 2 ada $50,0 \%$ responden, stadium 3 ada $37,5 \%$ responden, responden yang tidak bekerja yang tekanan darahnya stadium 1 ada12,5\% responden, stadium 2 ada $25,0 \%$ responden, stadium 3 ada $62,5 \%$ responden dari total sampel.

\section{Tabulasi Silang jumlah rokok yang dihisap dengan tekanan darah}

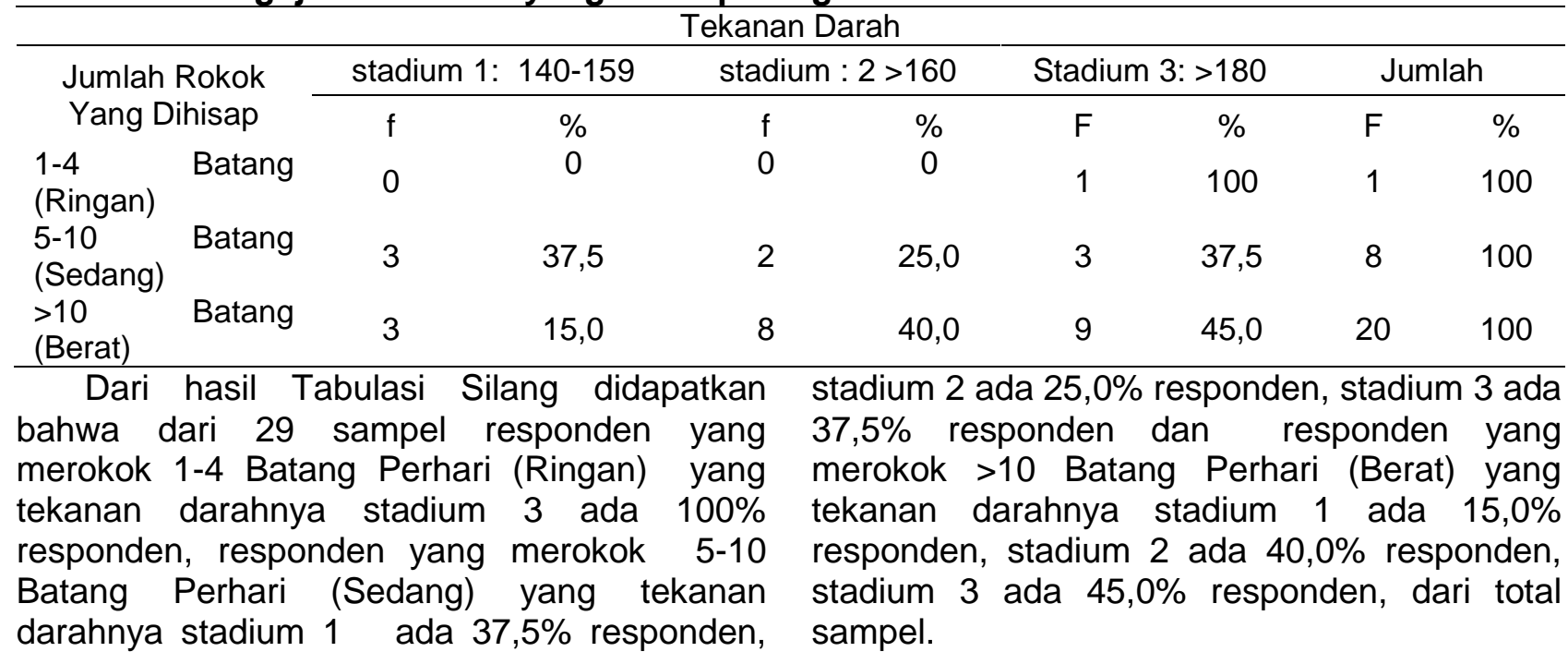


Tabulasi Silang Lama Merokok dengan tekanan darah

\begin{tabular}{ccccccccc}
\hline & \multicolumn{1}{c}{ Tekanan Darah } \\
\hline \multirow{2}{*}{$\begin{array}{c}\text { Lama menghisap } \\
\text { rokok }\end{array}$} & \multicolumn{2}{c}{ stadium 1: } & $140-159$ & \multicolumn{2}{c}{ stadium : $2>160$} & \multicolumn{1}{c}{ Stadium 3: $>180$} & \multicolumn{2}{c}{ Jumlah } \\
\cline { 2 - 9 } & $\mathrm{f}$ & $\%$ & $\mathrm{f}$ & $\%$ & $\mathrm{f}$ & $\%$ & $\mathrm{f}$ & $\%$ \\
\hline >10 tahun & 3 & 25,0 & 5 & 41,7 & 4 & 33,3 & 12 & 100 \\
$>20$ tahun & 3 & 17,7 & 5 & 29,4 & 9 & 52,9 & 17 & 100 \\
\hline
\end{tabular}

Dari hasil Tabulasi Silang didapatkan bahwa dari 29 sampel responden yang merokok >10 tahun yang tekanan darahnya stadium 1 ada 25,0\% responden, stadium 2 ada $41,7 \%$ responden, stadium 3 ada $33,3 \%$

responden, dan responden yang merokok $>20$ tahun yang tekanan darahnya stadium 1 ada $17,7 \%$ responden, stadium 2 ada $29,4 \%$ responden, stadium 3 ada 52,9\% responden, dari total sampel.

Tabulasi Silang jenis yang dihisap rokok dengan tekanan darah

\begin{tabular}{lcccccccc}
\hline \multirow{2}{*}{ Jenis rokok } & \multicolumn{1}{c}{ Stadium 1: } & $140-159$ & \multicolumn{2}{c}{ stadium : $2>160$} & \multicolumn{1}{c}{ Stadium 3: $>180$} & \multicolumn{2}{c}{ Jumlah } \\
\cline { 2 - 9 } & $\mathrm{f}$ & $\%$ & $\mathrm{f}$ & $\%$ & $\mathrm{f}$ & $\%$ & $\mathrm{f}$ & $\%$ \\
\hline \multirow{2}{*}{ Filter } & 5 & 26,3 & 5 & 26,3 & 9 & 47,4 & 19 & 100 \\
Non Filter & 1 & 10,0 & 5 & 40,0 & 4 & 40,0 & 10 & 100
\end{tabular}

Dari hasil Tabulasi Silang didapatkan bahwa dari 29 sampel responden yang merokok jenis Filter yang tekanan darahnya stadium 1 ada $26,3 \%$ responden, stadium 2 ada $26,3 \%$ responden, stadium 3 ada $47,4 \%$ responden, dan responden yang merokok Non Filter yang tekanan darahnya stadium 1 ada $10,0 \%$ responden, stadium 2 ada $50,0 \%$ responden, stadium 3 ada $40,0 \%$ responden, dari total sampel.

\section{PEMBAHASAN \\ Umur}

Dari tabel didapatkan bahwa hampir setengah responden berumur antara $60-74$ tahun yaitu sebanyak 14 responden $(48,3 \%)$, $\mathrm{Hal}$ ini sesuai dengan teori yang menyatakan bahwa tekanan darah cenderung rendah pada usia remaja dan mulai meningkat pada usia dewasa awal. Kemudian meningkat lebih nyata selama masa pertumbuhan dan pematangan fisik di usia dewasa ahir sampai usia tua di karnakan system sirkulasi darah terganggu, karena pembuluh darah sering mengalami penyumbatan dinding pembuluh darah menjadi keras dan tebal serta berkurangnya elastisitas pembuluh darah sehingga menyebabkan tekanan darah menjadi tinggi. (Guyton, 2007).

Semakin bertambahnya umur seseorang harus tetap memperhatikan kesehatan dengan menjaga kebugaran tubuh dengan berolah raga dan menjauhi kebiasaan buruk untuk mengurangi resiko penyakit hipertensi.

\section{Pendidikan}

Dari tabel didapatkan bahwa sebagian besar responden berpendidikan SD/Tidak Tamat SD yaitu sebanyak 17 responden $(58,6)$, menurut Nursalam (2003) makin tinggi tingkat pendidikan seseorang, makin mudah pula mereka menerima berbagai macam informasi tentang kesehatan atau pendidikan kesehatan, sehingga makin banyak informasi yang didapatkan. Sebaliknya jika pendidikan kesehatan tdk didapatkan maka akan menghambat perkembangan sikap seseorang terhadap nilai-nilai yang baru diperkenalkan.

Dari penelitian Nandang Tisna Ali Ami Jaya (2009) menyatakan bahwa terdapat hubungan antara pendidikan dengan kejadian hipertensi yang dilakukan di puskesmas pamulung kota tangerang selatan provinsi banten dengan jumlah sampel 77 yang berpendidikan SD/Tidak Tamat SD sebanyak 48 responden. Banyak informasi kesehatan yang kurang diperoleh responden baik dalam pendidikan formal maupun pendidikan non formal.

Seseorang yang pendidikannya rendah atau pengetahuannya kurang tentang penyakit yaitu salah satunya hipertensi itu harus lebih banyak bertanya apa itu penyakit hipertensi,faktor - faktor apa saja yang bisa menyebabkan hipertensi,supaya mereka bisa mengetahui faktor apa saja penyebab hipertensi dan bisa berhenti atau mengurangi kebiasaan buruknya salah satunya kebiasaan merokok dan mereka tidak terkena hipertensi.

\section{Pekerjaan}

Dari didapatkan bahwa hampir setengah responden bekerja sebangai wiraswasta yaitu sebanyak 9 responden $(31,1 \%)$, menurut Nursalam (2003) bahwa bekerja umumnya menciptakan kegiatan yang menyita waktu dan bekerja bagi seseorang mempunyai pengaruh terhadap kehidupannya. dengan bekerja maka seseorang akan sering meluangkan waktu di lingkungan tempat kerjanya sehingga jarang 
memikirkan hal lain kecuali masalah pekerjaannya dan sebaliknya. Umumnya penderita hipertensi mempunyai kecenderungan ada kaitannya dengan beban emosi (stres). Oleh karena itu disamping olahraga yang bersifat fisik dilakukan pula olahraga pengendalian emosi, artinya berusaha mengatasi ketegangan emosional yang ada.

Jumlah Rokok Yang Dihisap

Dari tabel 2.7 didapat bahwa sebagian besar responden perokok berat yaitu sebanyak 20 responden $(68,9 \%)$,menurut . (Suparto. 2000 : 74) dimana mereka mempunyai kebiasaan merokok lebih dari 10 batang perhari akan lebih memepercepat meningkatnya tekanan darah karena efek dari kandungan rokok tersebut, seperti karbon monoksida dapat menyebabkan terjadinya penyempitan pembuluh darah perifer, maka semakin banyak seseorang menghisap rokok akan semakin banyak pula karbon monoksida yang masuk dalam darah sehingga akan menyebabkan meningkatnya tekanan darah.

Berdasarkan Hasil dari penelitian Angela Novalia Tisa K. (2012) yang dilaksanakan di Nasmoco Semarang menunjukkan dari jumlah karyawan yang merupakan perokok ringan, sebagian besar tidak terjadi tekanan darah meningkat, sedangkan karyawan yang merupakan perokok sedang dan berat, sebagian besar dan bahkan seluruhnya pada perokok berat terjadi tekanan darah meningkat. Jadi perokok sedang dan berat lebih berisiko mengalami tekanan darah meningkat dari pada perokok ringan dan Kebiasaan merokok lebi dari 10 batang perhari itu sangat berisiko terjadi hal buruk pada kesehatan terutama yaitu hipertensi,sebaiknya mengurangi jumlah rokok yang dihisap setiap harinya atau berhenti merokok agar tidak hipertensi dan terkena hal buruk pada kesehatan .

\section{Lama Merokok}

Dari tabel didapat bahwa sebagian besar responden yang merokok $>20$ tahun yaitu sebanyak 17 responden (58,7\%), Menurut Rusli A. Mustofa (2005:3), yang menyatakan bahwa dampak rokok akan terasa setelah 1020 tahun pasca digunakan. Dengan demikian secara nyata dampak rokok berupa kejadian hipertensi akan muncul kurang lebih setelah berusia lebih dari 40 tahun, sebab dipastikan setiap perokok yang menginjak usia 40 tahun ke atas telah menghisap rokok lebih dari 20 tahun. Lebih tegas lagi Mangku Sitepoe (1997:19) yang menyatakan bahwa beberapa zat kimia dalam rokok bersifat kumulatif (ditambahkan), sehingga pada kurun waktu yang lama dosis racun akan mencapai titik toksin sehingga kelihatan gejala yang ditimbulkannya.Semakin dini seseorang menghisap rokok maka dengan bertambahnya umur semakin beresiko terkena hipertensi. Berdasarkan hasil diatas yang mempunyai kebiasaan merokok lebih dari umur >20 tahun sangat berisiko terkena hipertensi sebaiknya yang mempunyai kebiasaan merokok >20 tahun agar selalu berolah raga untuk mengurang resiko hipertensi.

\section{Jenis Rokok}

Dari tabel 2.9 didapat bahwa sebagian besar responden merokok jenis filter yaitu sebanyak 19 responden (65,5\%),jadi dalam penelitian ini,hipertensi yang di alami oleh responden ke banyakan merokok dengan jenis filter bukan non filter,hal ini tidak sama dengan teori yang di ungkapkan oleh (Mangku Sitepoe, 1997:24). Rokok yang tanpa filter akan lebih cepat di diserap oleh paru-paru sehingga resiko hipertensi akan lebih besar dibandingkan perokok yang berfilter dan hasil penelitian dari Fajar Haninda Nurcahyani (2003). Terdapat hubungan antara jenis rokok yang dihisap dengan kejadian hipertensi,rokok yang tanpa filter akan lebih cepat di diserap oleh paru-paru sehingga resiko hipertensi akan lebih besar dibandingkan perokok yang berfilter. Dari dua jenis rokok diatas itu sama - sama bisa menyebabkan resiko hipertensi karena kandungan dari dua jenis rokok tersebut sama yaitu mengandung nikotin,karbon monoksida,timah hitam dan tar,yang dimana zat - zat tersebut bisa menyebabkan hipertensi.

\section{Waktu Merokok}

Didapatkan bahwa sebagian besar responden waktu merokok habis makan yaitu sebanyak 16 responden (55,1\%), Menurut (Thompson, 1992). memakan makanan juga merupakan tuntutan manusia yang bersifat berulang-ulang sehingga ada antara merokok dengan kebiasaan makan, pola makan, dan penggunaan bahan makanan.

Kebiasaan di Indonesia, orang akan merokok setelah makan. Menurut mereka, kenikmatan merokok akan lebih nikmat sesudah makan dengan sayuran yang pedas.Selain itu, monosodium glutamat (MSG) atau vetsin yang menambah cita rasa makanan juga menambah kenikmatan merokok (Merck Index, 1991).Dari data diatas kebanyakan orang merokok sehabis makan,menurut mereka kenikmatan rokok lebih terasa apabila dihisap sehabis makan. Untuk yang mempunyai kebiasaan merokok sesudah makan sebaiknya mengemel permen agar kebiasaan merokok 
sehabis hilang dan dapat mengurangi resiko hipertensi.

\section{Umur Dengan Tekanan Darah}

Dari tabel tampak responden terbayak pada umur 60 - 74 tahun yang tekanan darahnya stadium 3 ada 7 responden atau $24,1 \%$, dari total sampel. Menurut teori (Guyton, 2007).menyatakan bahwa tekanan darah cenderung rendah pada usia remaja dan mulai meningkat pada usia dewasa awal. Kemudian meningkat lebih nyata selama masa pertumbuhan dan pematangan fisik di usia dewasa ahir sampai usia tua di karnakan system sirkulasi darah terganggu, karena pembuluh darah sering mengalami penyumbatan dinding pembuluh darah menjadi keras dan tebal serta berkurangnya elastisitas pembuluh darah sehingga menyebabkan tekanan darah menjadi tinggi. Semakin bertambahnya umur seseorang rentan terkena hipertensi,karena pembuluh darah sering mengalami penyumbatan dinding pembuluh darah sehingga menyebabkan tekanan perifer sehingga menyebabkan tekanan darah naik. Dengan bertambahnya umur seseorang harus tetap memperhatikan kesehatan dengan menjaga kebugaran tubuh dengan berolah raga dan menjauhi kebiasaan buruknya serta sering memeriksakan kesehatnya ke tempat kesehatan terdekat.

\section{Pendidikan dengan tekanan darah}

Dari tabel tampak responden terbayak yang berpendidikan SD/Tidak Tamat SD yang tekanan darahnya stadium 3 ada 8 responden atau $27,5 \%$, dari total sampel. menurut Nursalam (2003) makin tinggi tingkat pendidikan seseorang, makin mudah pula mereka menerima berbagai macam informasi tentang kesehatan atau pendidikan kesehatan, sehingga makin banyak informasi yang didapatkan. Sebaliknya jika pendidikan kesehatan tdk didapatkan maka akan menghambat perkembangan sikap seseorang terhadap nilai-nilai yang baru diperkenalkan.Banyak informasi kesehatan yang kurang diperoleh responden baik dalam pendidikan formal maupun pendidikan non formal. Pengetahuan juga dapat dipengaruhi oleh pendidikan seseorang, namun tidak menutup kemungkinan pada seseorang yang pendidikannya tinggi mempunyai pengetahuan yang kurang. Dengan demikian makin banyak informasi yang didapat mengenai kesehatan maka pengetahuan seseorangpun makin baik pula.

\section{Pekerjaan dengan tekanan darah}

Dari tabel tampak responden terbayak yang tidak bekerja yang tekanan darahnya di stadium 3 ada 5 responden atau 17,3\% dari total sampel. Menurut (Smet, Bart,1994:244) Stres pada pekerjaan cenderung menyebabkan hipertensi berat. Sumber stres dalam pekerjaan ( Stressor) meliputi beban kerja, fasilitas kerja yang tidak memadai, peran dalam pekerjaan yang tidak jelas, tanggung jawab yang tidak jelas, masalah dalam hubungan dengan orang lain, tuntutan kerja dan tuntutan keluarga. Semakin tingginya tingkat ekonomi seseorang maka seseorang cenderung mengalami perubahan perilaku terhadap kebiasaan buruk yang berdampak negatif terhadap status kesehatannya. Dimana Kebiasaan tersebut merupakan cerminan dari tindakan yang dilakukan setiap hari dan berdampak buruk bagi kesehatannya.

\section{Jumlah Rokok Yang Dihisap Dengan Tekanan Darah}

Dari tabel tampak responden terbayak yang merokok > 10 batang (Berat) perhari ada 3 responden atau $10,4 \%$ yang tekanan darahnya stadium 3 ada 9 responden atau $31,1 \%$, dari total sampel.Dimana mereka mempunyai kebiasaan merokok lebih dari 10 batang perhari akan lebih memepercepat meningkatnya tekanan darah karena efek dari kandungan rokok tersebut, seperti karbon monoksida dapat menyebabkan terjadinya penyempitan pembuluh darah perifer, maka semakin banyak seseorang menghisap rokok akan semakin banyak pula karbon monoksida yang masuk dalam darah sehingga akan menyebabkan meningkatnya tekanan darah. (Suparto. $2000: 74$ )

\section{Lama merokok dengan tekanan darah}

Dari tabel tampak responden terbayak yang merokok >20 yang tekanan darahnya stadium 3 ada 9 responden atau $31,0 \%$ dari total sampel. Menurut Rusli A. Mustofa (2005:3), yang menyatakan bahwa dampak rokok akan terasa setelah 10-20 tahun pasca digunakan. Dengan demikian secara nyata dampak rokok berupa kejadian hipertensi akan muncul kurang lebih setelah berusia lebih dari 40 tahun, sebab dipastikan setiap perokok yang menginjak usia 40 tahun ke atas telah menghisap rokok lebih dari 20 tahun. Lebih tegas lagi Mangku Sitepoe (1997:19) yang menyatakan bahwa beberapa zat kimia dalam rokok bersifat kumulatif (ditambahkan), sehingga pada kurun waktu yang lama dosis racun akan mencapai titik toksin sehingga kelihatan gejala yang ditimbulkannya. Dimana 
Secara umum rokok dapat dibedakan menjadi dua jenis yaitu rokok filter dengan rokok non filter. Dibandingan rokok filter, rokok non filter memiliki kandungan nikotin dan tar lebih besar. Dengan kandungan nikotin dan tar yag lebih besar dan tidak disertai penyaring pada pangkal batang rokok, maka potensi masuknya nikotin dan tar ke dalam paru-paru dari rokok non filter akan lebih besar daripada rokok filter yang berdampak buruk pada pemakainya dan salah satunya akan terkena risiko hipertensi. Efek nikotin menyebabkan perangsangan terhadap hormon kathekolamin (adrenalin) yang bersifat memacu jantung dan tekanan darah. Jantung tidak diberikan kesempatan istirahat dan tekanan darah akan semakin meningkat, berakibat timbulnya hipertensi.

\section{SIMPULAN DAN SARAN}

\section{Simpulan}

1. Setengah $14(48,3 \%)$ berumur $60-74$ tahun.

2. Sebagian besar $17(58,6 \%)$ berpendidikan SD/Tidak Tamat SD.

3. Hampir Setengah $9(31,0 \%)$ pekerjaannya Wiraswasta.

4. Hampir Setengah 13 (44,9\%) tekanan darah responden stadium 3.

5. Sebagian besar $20(69,0 \%)$ merokok lebih dari $>10$ dalam sehari .

6. Sebagian besar $17(58,6 \%)$ merokok $>20$ tahun.

7. Sebagian besar $19(65,5 \%)$ merokok jenis filter.

8. Sebagian besar $16(55,1 \%)$ merokok setelah makan.

\section{Saran \\ Bagi Responden}

Agar lebih banyak mencari informasi tentang bahaya merokok dan penyakit apa saja yang dapat ditimbulkan oleh kebiasaan merokok.

\section{Bagi Profesi}

Agar lebih meningkatkan pemberian informasi kepada perokok dalam bentuk penyuluhan tentang bahaya merokok.

\section{Bagi Institusi Pendidikan}

Agar lebih mempersiapkan calon tenaga kesehatan dengan baik, karena keadaan di masyarakat sangat berbeda dengan teori yang disampaikan.

\section{Bagi Peneliti Lain}

Agar dapat melanjutkan penelitian ini kearah yang lebih spesifeik lagi, sehingga kita dapat mengetahui apa yang menjadi faktor seseorang memiliki kebiasaan merokok.

\section{DAFTAR PUSTAKA}

Adnil Basha. 2004. Hipertensi: Faktor Resiko Dan Penatalaksanaan.

Arif Mansjoer, dkk. 2000. Kapita Selekta Kedokteran jilid I. Jakarta: Media Aesculapius.Jurnal Keolahragaan Universitas Negeri Semarang

Arjatmo T, Hendra U.2001. Ilmu Penyakit Dalam. Balai Penerbit FKUI.

Anies,2006. Waspada ancaman penyakit tidak menular. Jakarta: Gramedia.

Beevers D.G. 2002. Tekanan Darah. Jakarta: Dian Rakyat. Jurnal Keolahragaan Universitas Negeri Semarang

Bustan, M.N. 2000. Epidemiologi Penyakit Tidak Menular. Rineka Cipta: Jakarta.

Hidayat, Aziz Alimul (2007). Metode Penelitian Keperawatan dan Teknik Analisa Data, Jakarta : Salemba Medika .

Lanny Sustrani, dkk. 2004. Hipertensi. Jakarta. PT. Gramedia Pustaka Utama.

Komarasari, D.\&Helmi, AF. (2000). FaktorFaktor penyebab perilaku merokok pada remaja. Jurnal Psikologi Universitas Gadjah Mada, 2. Yogyakarta: Universitas Gadjah Mada Press

Mangku, Sitepoe. 1997. Usaha Mencegah Bahaya Merokok. Jakarta:Gramedia. Jurnal Kesehatan Universitas Esa Unggul Jakarta

Notoatmodjo, Soekidjo, 2005, Metodologi Penelitian Kesehatan, Edisi revisi, Rineka. Jurnal Kesehatan Universitas Esa Unggul Jakarta

Nursalam (2008). Konsep dan Penerapan Metedologi Penelitian IImu Keperawatan, Jakarta : Salemba Medika

Sani A., 2008. Hypertension current perspective. Jakarta: Medya Crea. Jurnal Fakultas Kedokteran UPN " Veteran " Jakarta 